\title{
Educational and Occupational Plans of Rural Youths
}

\begin{abstract}
The purpose of this paper is to describe the educational and occupational plans of rural youths in rural schools and related students' educational and occupational choice to the needs of the country. The findings showed that almost all students participated in the aspired for education beyond the secondary schools. The two most popular program students expect to enroll at the tertiary level were accountancy and engineering. All of the respondents have tentatively made their career choices. It also shows that respondents have some knowledge as to subjects important for their educational and career choices.
\end{abstract}

Keyword: Educational Plans, Occupational Plans 